\title{
An impact evaluation of area-based interventions in Cape Town using multivariate regression analysis
}

\section{Herman Geyer}

http://dx.doi.org/10.18820/2415-0495/trp69i1.2

Peer reviewed and revised

\begin{abstract}
Area-based initiatives are popularly applied to alleviate the spillover effects of neighbourhood poverty in deprived neighbourhoods. This study analyses the effects of two area-based initiatives on neighbourhood poverty in Cape Town between 2001 and 2011 in a controlled baseline study. The purpose of this study is to determine whether the changes were the product of policies themselves or wider structural changes in the national economy, and what were the specific outcomes of the policies. The study revealed that, despite some minor gains, these policies were ineffective in reducing poverty levels in the policy areas, and that poverty levels are primarily determined by the broader changes in the economic environment and in-migration.
\end{abstract}

Keywords: Area-based policy, neighbourhood poverty, redistribution policies, South Africa

\section{'n IMPAK-EVALUERING VAN STREEKSINGRYPINGS IN KAAPSTAD DEUR MIDDEL VAN MEERVERANDERLIKE REGRESSIE-ANALISE}

Streeksinisiatiewe word gereeld geïmplementeer om die nagevolge van buurtar moede in arm buurte te verlig. Hierdie studie analiseer die uitkomste van twee streeksinisiatiewe op buurtarmoede in Kaapstad tussen 2001 en 2011 in 'n gekontroleerde basislynstudie. Die doel van die studie is om te bepaal of die uitkomste die produk van beleid self was of was as gevolg van die groter strukturele veranderings in die nasionale ekonomie. Verder is die spesifieke beleidsuitkomste ook geanaliseer. Die studie het bepaal dat, ondanks klein aanwinste, hierdie beleide hoofsaaklik oneffektief was in die strewe om buurtarmoede in die beleidsgebiede te verlaag, en dat armoedsvlakke hoofsaaklik deur groter veranderinge in die ekonomiese omgewing en in-migrasie bepaal is.

Sleutelwoorde: Streeksgebaseerde beleid, omgewingsarmoede, Suid-Afrika, herverdelingsbeleide

\section{TEKOLO E NANG LE TSHUSUMETSO YA MESEBETSI E ITSHETLEHILENG SEBAKENG KA HARE HO KAPA (CAPE TOWN), KA HO SEBEDISA TLHOPHOLLO YA KGUTLELO MORAO YA DIPHETOHO TSE NGATA (MULTIVARIATE REGRESSION ANALYSIS)}

Boithaopo bo itshetlehileng hodima dibaka bo sebediswa haholo ho fedisa ditlamorao tsa bofuma ba tikoloho tse mabapi, ditikohong tse ka tlasa kgatello. Thuto ena e hlopholla ditlamorao tsa boithaopo bo itshetlehileng hodima dibaka tse pedi bofumeng ba tikoloho e mabapi ka hare ho Kapa (Cape Town) mahareng a dilemo tsa bo 2001 le 2011, thutong ya motheo e tlasa taolo. Sepheo sa thuto ena ke ho netefatsa hore na diphetoho e bile ditlamorao tsa melawana kapa diphetoho tse kgolo tse entsweng ke moruo wa naha, hape le hore ditlamorao tsa melawana e bile dife. Thuto ena e hlahisitse hore ntle le ho sheba diphaello tse nnyane, melawana ena e ne e sa sebetse bakeng sa ho theola maemo a hodimo a bofuma dibakeng tseo melawana e sebediswang ho tsona, mme maemo a bofuma haholo a lekanngwa ke diphetoho tse akaretsang tikolohong e amang moruo le bofalli. Ho ya ka diphetho le diphumano tsa diphuputso, karolo ya tsamaiso ya toropo (e nngwe ya dikarolo tsa morero wa lerato la bophelo "Biophilic planning", ke mosebetsi o ka sehloohong bakeng sa ho fumana toropo ya bodulo bo bolokehileng. Sephetho sa thuto ena se bohlokwa haholo bakeng sa kaho le ditho tsa sehlopha sa thero ya ditoropo, bareki le ba dithuto tsa tikoloho. Lebaka le leng ke le amang haholoholo dinaha tseo di sa ntseng di hola,e leng moo ho nang le bokgoni bo matla ba thaho le diindasteri tse amehang; ho etsa ditshusumetso tse molemo bakeng sa setjhaba le moruo.

\section{INTRODUCTION}

Area-based policies are developed to spatially target resources and policy interventions in selected deprived locations, in order to reduce poverty in areas where it is concentrated (Alcock, 2004: 90). However, many analysts are critical of the manner in which area-based initiatives (ABIs) are implemented, arguing that concentrated urban poverty is a spatial side effect of aspatial policies (Logan \& Molotch, 1987: 56; Wilson, 1987: 13). They argue that the root cause of spatially concentrated poverty is structural policies, and that $A B I s$ will be ineffective in addressing concentrated poverty.

In light of this debate, the study evaluates the effectiveness of two ABls targeting specific neighbourhoods in Cape Town in terms of changes in neighbourhood poverty between 2001 and 2011. The first is the urban renewal programme (URP), a nationally driven pilot $A B I$ implemented in Khayelitsha and Mitchells Plain between 2001 and 2011. The second is the spatially targeted municipal area-based investment in neighbourhoods designated as marginalised areas by the 2004 Cape Town SocioEconomic Index (henceforth known as municipal area-based initiatives or MABIs). Additionally, the study uses a control group of high-poverty neighbourhoods, where the ABIs

The author declares no conflict of interest for this title or article.

Mr Herman S. Geyer Jr. Researcher: CRUISE Centre, Department of Geography, Geolnformatics, Urban and Regional Planning, Stellenbosch University. Room 2046, Kamer van Mynwese Building, 20 Van Ryneveldt Street, Stellenbosch 7600, South Africa. Phone: (+27) 218089223, email: <hsgeyerjr@sun.ac.za> 
were not implemented, in order to comparatively evaluate variations in changes in neighbourhood poverty between 2001 and 2011 in a controlled baseline study. The study employs multivariate regression analysis to analyse the socio-economic characteristics of neighbourhood change in neighbourhoods with high poverty. Cape Town was selected as the study area because of the comparative use of different $\mathrm{AB}$ Is within comparable sample populations and because of the diversity of neighbourhoods in the municipality.

\section{AREA-BASED APPROACHES}

Poor neighbourhoods experience proportionally higher rates of deprivation, including unemployment, welfare dependency, crime, morbidity and educational underachievement. The spatial concentration of these phenomena intensifies economic and social deprivation in these neighbourhoods in a milieu of ever-increasing affluence (Wilson 1987: 26). This poses a political problem in a welfareoriented state, as the concentration of poverty indicates a failure of policy to integrate populations and redistribute wealth (Musterd \& De Winter, 1998: 669). In an attempt to minimise the negative externalities of concentrated poverty, ABIs spatially target additional resources in the most deprived areas. They also address these problems by increasing economic participation and strengthening social agency in specific locations. Thus, ABls attempt to directly target a greater number of deprived households than can be targeted by way of structural policies (Smith, 1999: 13).

More recently, third-way approaches also included smaller social projects, including childcare support, job-placement programmes, neighbourhood policing, educational, health and sporting programmes to promote social agency as well as a move towards collaborative selfgoverning partnerships and thirdsector participation (Lawless, Foden, Wilson \& Beatty, 2010: 262). Third-way approaches are based on subcultural theories, in which it is believed that social agency can be channelled to regenerate an area without displacement by utilising existing social and cultural ties to a neighbourhood.

Strong community dialogue and social interactions within a community can increase the attachment of residents to the neighbourhood, thus motivating residents to invest in their own neighbourhoods and stabilise the community (Temkin \& Rohe, 1996: 165; Andersson \& Musterd, 2005: 380).

While the concentration of urban poverty is a problem in both developed and developing countries, this problem is particularly acute in South Africa. Spatially, urban poverty is still concentrated in former apartheid-era Black townships, indicating that post-apartheid policy had hardly any effect on changing the spatial structure of apartheid (Noble \& Wright, 2013: 188). In response, the South African government has piloted $A B I s$ targeting the distribution of public resources in selected deprived urban areas in South Africa. The intention of area-based planning in South Africa is to change the character of a location by means of a range of institutional mechanisms involving private, governmental and local stakeholders, in order to achieve the development objectives of local and regional planning policies (Turok, 2004: 409).

Post-1994, one of the first presidential initiatives was the implementation of 13 special integrated presidential projects (SIPPs). These pilot ABIs were primarily geared towards rapid housing and infrastructure roll-outs in former township areas, demonstrating state commitment to expand public works and basic services delivery in poor neighbourhoods. Presidential championing enabled generous foreign donor funding and the continuation of a number of these initiatives, despite the cancellation of the Reconstruction and Development Programme in early 1996. Despite the mixed performance of SIPPs, certain projects were relatively successful and formed the foundation for the 2001-2011
URP (Prak, Robinson, McCarthy \& Forster, 2004: 178; Harrison, Todes \& Watson, 2007: 21).

\subsection{Urban renewal programme}

The URP was an intergovernmental co-ordinated 10-year ABI implemented in eight former townships throughout South Africa. Selection criteria included locations with high poverty levels, high crime rates, low economic opportunities, low social capital, high unemployment rates, low education rates and low skill levels (DPLG, 2004). The purpose of the URP was to crowd in investment in previously disenfranchised neighbourhoods, mobilise partnerships with local investors, and strengthen public participation (Forster, Leon \& Menguele, 2006: 16). Different government tiers, ${ }^{1}$ government departments, quangos, the private sector and community trusts representing local stakeholders cooperated in developing the projects. No dedicated funding mechanism was provided. Instead, stakeholders were required to implement existing financing mechanisms available to all three tiers of government. Moreover, the URP was also tasked to balance structure with agency, combining infrastructure roll-outs with community-driven economic and social development projects. Most importantly, the URP aimed to stimulate the replication of spin-off ABls by stakeholders subsequent to the programme (DPLG, 2007a: 26).

In the study area, two URP programmes were implemented in Mitchells Plain and Khayelitsha. Local government provided basic services and coordinated the project; national government provided housing and access to a number of national developmental funds, and provincial government departments provided transportation, infrastructure and health-service infrastructure. Private investment was limited to retail and affordable middle-income housing development. URP outputs in Cape Town included the extension and improvement of transportation infrastructure, public housing,

1 Local, provincial, and national. 
state-subsidised affordable private housing, the construction of a district hospital, clinics, magistrate's courts, sport and recreational facilities, greening projects, city beautification projects, and the development of retail facilities. Through local consultation, the Cape Town URP also developed a number of comparatively inexpensive quick-win projects, including brush and canal clearing, the retrofitting of public housing with energy-saving devices, and implementing skills development courses (CoCT, 2011a: 35;

Donaldson, Du Plessis, Spocter \& Massey, 2013: 633; Donaldson \& Du Plessis, 2013: 299).

However, the results of the URP were somewhat disappointing. The coordinated inter-governmental planning process was painstakingly slow, due to institutional flux, political rivalry, extensive reporting requirements, rigorous procurement procedures and continuous community consultation (Donaldson \& Du Plessis, 2013: 297). Developments were often not aligned with the priorities of local IDP and SDF policies and URP projects duplicated existing local and provincial projects in many instances. In many of the projects, the government departments responsible for these functions did not implement social programmes (DPLG, 2007b: 46). Economic development was primarily focused on subsidising the establishment of national retail chains in large shopping centres, resulting in the decline in informal trading in areas surrounding the retail development (Donaldson \& Du Plessis, 2013: 298). Most of the housing developed were state-subsidised, private, middleincome developments instead of free low-income housing, and were unaffordable to the majority of the residents in the area (Siyongwana \& Mayekiso 2011: 149). These developments created a net leakage of local disposable income out of the community. Finally, government expenditures were not equally distributed within the selected areas, with the most impoverished sections of these neighbourhoods often neglected for more profitable developments in central locations within the ABI (DPLG, 2007b: 23).

\subsection{Municipal area-based initiatives}

In addition, the Cape Town Metropolitan Municipality also implemented targeted area-based investment in MABls. Although not designated as $A B I s$, the marginalised areas were identified using the 2004 Cape Town Socio-Economic Index to identify subplaces within the municipality that had the greatest levels of deprivation (CoCT, 2014). Based on this Index, national census subplaces, representing neighbourhoods by proxy, were ranked in terms of household service levels, education rates, housing type and household income. The ranking was weighted towards neighbourhoods that had lower service levels and less adequate housing, not absolute income poverty levels per se, and the purpose of the policy was to lower all forms of poverty in the selected areas (Laldahprasad, Geyer Jr \& Du Plessis, 2013: 42). Accordingly, different departments within the municipality coordinated to target services in areas delineated as deprived.

Cape Town municipal expenditures were significantly higher in areas that required the greatest need for public intervention, indicating an efficient implementation of the MABIs (Laldahprasad et al., 2013: 44). The $\mathrm{MABI}$ projects replicated many of the URP outcomes throughout the municipality, and collaborated with the URP within its demarcated area; marginalised areas were effectively prioritised (CoCT, 2011b: 47). These replications included public housing, public transportation, hospitals and clinics, public retail facilities and basic services infrastructure. However, tasked with a broader range of objectives, and being held accountable by city managers, the MABIs also included smaller initiatives such as the development of tourism information offices, fresh-produce markets, informal trading markets, sports facilities, arts facilities, libraries, community centres, and recreational parks (CoCT, 2011c: 33).

\section{CHALLENGES FACING AREA-BASED INITIATIVES}

From the outset, the performance of these ABIs highlight two basic challenges in area-based approaches, the first being the challenge of defining poverty and the spatial delineation of poverty. Poverty is generally defined in terms of the mean standard of living of persons in a pluralistic society (Goedemé \& Rottiers 2011: 78). On that basis, poverty is related to the availability of choices and opportunities to individuals; poverty is thus multidimensional. However, because basic needs such as employment, health, education, housing, public services and a safe environment are ultimately attributed to income variations, household income is nearly universally employed to measure poverty. Defining spatial distribution of poverty is an equally difficult task. While neighbourhood poverty is generally analysed in terms of administrative boundaries, the neighbourhood is not a closed system; it is nested within larger social and economic networks with a fluid population. However, as the aggregate measures of socioeconomic indicators are similar at different levels of spatial aggregation, the official administrative spatial delineation of neighbourhoods is a useful proxy (Galster, 2001: 2113).

A second serious challenge is how to determine the effectiveness of $\mathrm{ABI}$ in reducing poverty. Commercial property development in impoverished areas rarely attracts outside industries, due to negative externalities in terms of location to markets, suitable skilled labour, and suppliers. The majority of local relocations consist of the pitchshifting of existing local enterprises vacating derelict property in favour of upgraded property. The number and quality of jobs produced are marginal, and primarily consist of part-time, low-wage, unskilled jobs at the loss of locally owned and managed enterprises and the declining circulation of local disposable income (Turok, 1992: 369). Furthermore, the physical restructuring of the neighbourhood through retail-led regeneration does not address the 
key problems of unemployment, criminality and welfare dependency (Andersson \& Musterd 2005: 384). The displacement of poor residents to the worst neighbourhoods often occurs through the overt redevelopment and relocation of existing low-income communities, ostensibly through low-income housing redevelopment, crimemitigation programmes or environmental revitalisation programmes (Smith, 2002: 438).

Prestige projects tend to be concentrated in the most profitable locations and, although located in close proximity to the disadvantaged, there is very little synergy or interdependency other than the most superficial interaction.

\section{METHODOLOGY}

The study evaluates the effectiveness of ABls in Cape Town in terms of changes in neighbourhood poverty between 2001 and 2011. Cape Town was chosen as the study area, due to the large number of neighbourhoods and the diversity of neighbourhood types in the municipality. The critical question in the study is whether the observations are attributable to ABls or not. Thus the study takes the approach that appropriate $A B I$ evaluations should evaluate policy outcomes independent of broader regional changes in neighbourhoods. To accomplish this, the study uses best subset linear multivariate regression analysis in a differencein-differences (DD) methodology to determine the variables best correlated with policy effects. DD is a statistical technique that creates an experimental research design, using observational study data to mitigate the effects of extraneous factors and selection bias by comparing the change over time in the treatment group to the change over time in the control group (Abadie, 2005: 1). This maximises the internal validity of the findings and thus the reliability of the study results.

\subsection{Data collection}

The study has two study groups and a control group. The primary study group consists of the Mitchells Plain and Khayelitsha census subplaces, in which the URP was implemented. The second study group consists of subplaces designated as MABIs according to the 2004 Cape Town Socio-Economic Index, in which municipal resources were targeted for social upliftment. The control group consists of subplaces in the Cape Town Metropolitan Municipality, which were not selected for either the URP or the MABI, but had propensity scores similar to the treatment groups based on the 2001 Census data baseline attributes. These specific baselines are linked to the selection criteria of the URP (poverty rates) and the 2004 Cape Town SocioEconomic Index (poverty rates and unemployment levels) (CoCT, 2014; DPLG, 2007c: 5). Propensity score matching was done based on the neighbourhood poverty rates and unemployment rates. These baseline attributes were selected, because they consisted of variables whose means fitted within the confidence interval of the treatment sample baseline attributes at a $95 \%$ confidence interval.

The study period between 2001 and 2011 is selected for a DD analysis, because it falls within both the implementation period of the two policies analysed and the two census periods from which the majority of the data was collected. The main source of the data is Census 2001 and Census 2011 data at subplace level. However, the analysis also used additional spatial weighted data, including 2011 hedonic property data from the CoCT property register role, police crime statistics, GVA from the Development Bank of Southern Africa, and the total budgeted state investment from the CoCT budget reports, including both the URP and $\mathrm{MABI}$ project budgets.

\subsection{Data analysis and interpretation}

The first analysis estimates the correlation between the policy and changes in neighbourhood poverty between 2001 and 2011 in the entire municipality, in order to determine whether policy was a significant factor in neighbourhood poverty change in the study area during the study period. In the second analysis, the study determines what factors are significantly correlated to changes in neighbourhood poverty within the treatment and control groups between 2001 and 2011 using a DD methodology. Controlling for broader changes in regional attributes in the control group, the neighbourhood poverty change as a product of policy itself can be significantly correlated in the treatment groups. This is done to determine the effectiveness of $\mathrm{ABI}$ policies, independent of broader changes in regional attributes.

The study selected the subset of factors best predicting changes in neighbourhood poverty by reducing the number of variables while maximising the coefficient of determination. Table 1 lists the variables included in the study. Income poverty, the dependent variable, is measured in terms of the percentage of household incomes above the poverty line. Income poverty was selected as the appropriate measure, because multivariable poverty indexes can result in variance inflation, due to multicollinearity; the ad hoc selection of multivariables results in adverse selection based on the composition of the Index (Jargowsky 2003: 47; Bhorat, Oosthuizen \& Van Der Westhuizen, 2012: 79). Although it is difficult to select an adequate parameter to measure change in poverty in neighbourhoods, given the multidimensional nature of poverty, neighbourhood poverty status is best determined by the proportion of low-income households in a spatially defined neighbourhood as an intuitive proxy measure of neighbourhood change (Ren, 2012: 29). The study uses the municipal free basic services poverty line to estimate the poverty rate, because it is a local measure used throughout the study period; it is a method most favoured by researchers (Jargowsky, 2003: 66), and is periodically adjusted for inflation. Most of the data comes from 2001 and 2011 census data at 2011 subplaces. The neighbourhood poverty rate is the proportion of the total number of households in the neighbourhood with annual household incomes below the poverty line. 
Table 1: Variables included in the study

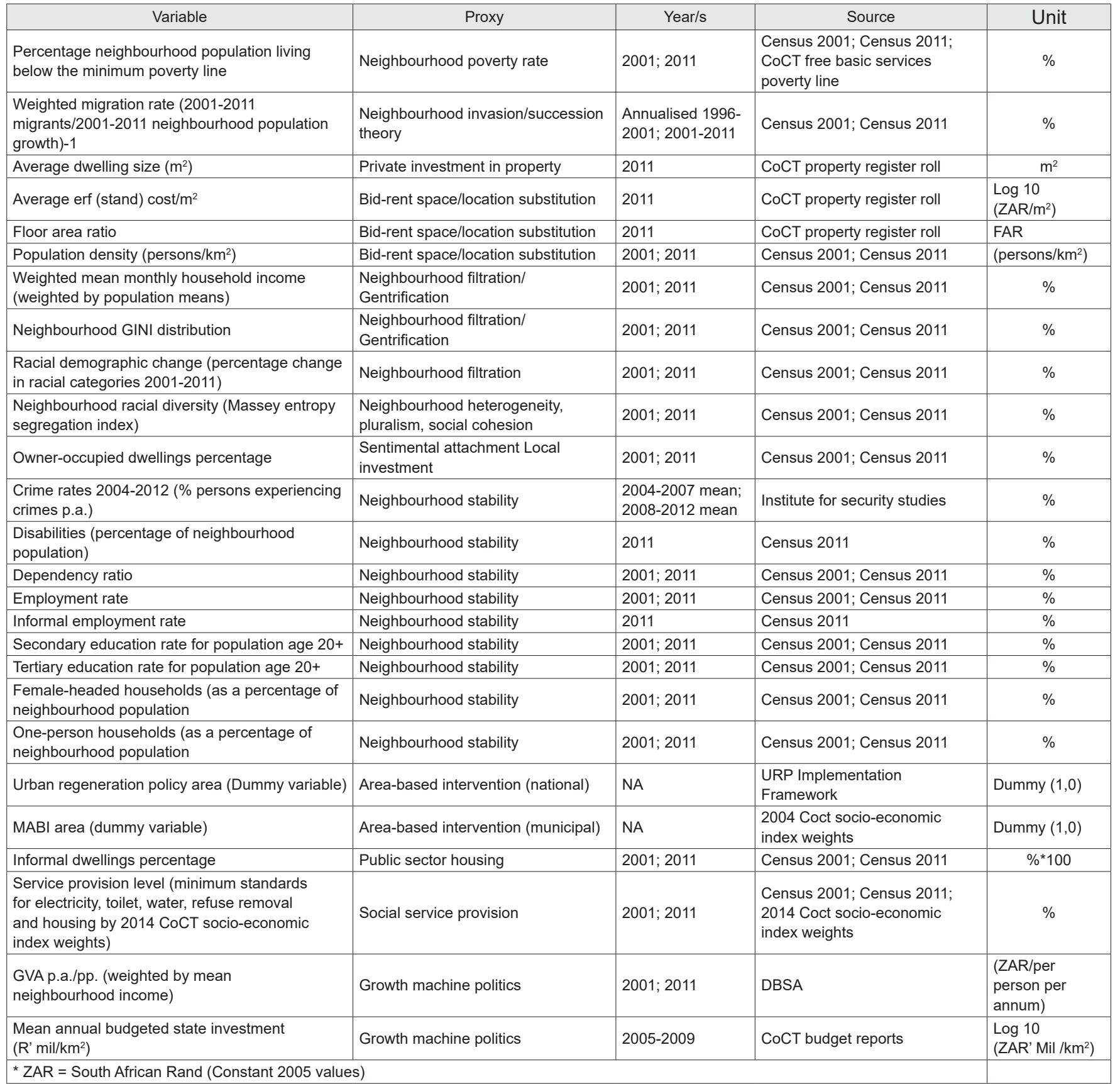

\section{1 census subplace areas were} used as proxies for neighbourhoods, because they were developed along local urban boundaries equivalent to split or merged suburbs. Seven hundred and thirty-four subplaces were selected for analysis. The criteria for the selection of subplaces were that they contain a 2001 population of over 100 persons; they are not located in commercial or industrial centres, nature reserves or predominantly rural areas; there are no missing data values; they contain no significant institutionalised, retirement or student residence populations, and neighbourhoods did not experience a population increase of over $300 \%$ between 2001 and 2011 (not very large, given the population nearly doubled between 1994 and 2011). It was impossible to develop a sufficiently sized study sample with low migration data, due to the high migration rates. The data was also trimmed of subplaces with variables beyond two standard deviations or $95 \%$ of the population mean to reduce the effect of outliers. The URP dataset contains 46 observations, the MABI dataset contains 57 subplace observations, and the control group contains 61 subplace observations.

\section{ANALYSIS}

The purpose of the first analysis is to determine whether $A B I$ policies were a significant factor in neighbourhood poverty change in the study area. The first analysis, presented in Table 2, presents a regression analysis of factors related to changes in neighbourhood poverty between 2001 and 2011. These present the best estimate of non-interdependent predictor independent variables. Variables included the change between 2001 and 2011 values of independent variables for each observation, as well as locational attributes and dummy variables. 
Table 2: Multiple regression analysis of factors related to changes in neighbourhood poverty, 2001-2011.

TOTAL Best subset regression; DV: poverty trajectory 2001-2011 (positive value = increased poverty), $R=.6995, R^{2}=.4831$, Adj $R^{2}=.4808, F(12,734)=57.569, p<0.0001$, Std. Err: .06445

\begin{tabular}{|l|c|c|c|c|c|}
\hline \multicolumn{1}{|c|}{$N=734$} & $b$ & $\begin{array}{c}\text { Std. Err. } \\
\text { (of } b \text { ) }\end{array}$ & $t(734)$ & $p$-value & \# best 20 \\
\hline Intercept & 0.3889 & 0.0351 & 11.0818 & 0.0000 & 20 \\
\hline$\Delta$ Property value (\% of munic. mean) & -0.0056 & 0.0024 & -2.3676 & 0.0182 & 20 \\
\hline$\Delta$ Household income (\% of munic. mean) & -0.0247 & 0.0049 & -5.0035 & 0.0000 & 20 \\
\hline$\Delta$ Neighbourhood GINI (\%) & 0.3611 & 0.0302 & 11.9494 & 0.0000 & 20 \\
\hline$\Delta$ Informal dwelling ratio (\%) & 0.1500 & 0.0225 & 6.6571 & 0.0000 & 20 \\
\hline$\Delta$ Racial heterogeneity (\%) & -0.0368 & 0.0126 & -2.9337 & 0.0035 & 20 \\
\hline$\Delta$ Dependency ratio (\%) & 0.0738 & 0.0233 & 3.1726 & 0.0016 & 20 \\
\hline$\Delta$ Employment rates (\%) & -0.1775 & 0.0292 & -6.0768 & 0.0000 & 20 \\
\hline$\Delta$ Tertiary education rate (\%) & -0.1442 & 0.0275 & -5.2496 & 0.0000 & 20 \\
\hline$\Delta$ Female-headed households ratio (\%) & 0.1024 & 0.0280 & 3.6592 & 0.0003 & 20 \\
\hline$\Delta$ Neighbourhood GVA (\% of munic. mean) & -0.0197 & 0.0070 & -2.8153 & 0.0050 & 20 \\
\hline URP (dummy) & 0.0227 & 0.0104 & 2.1719 & 0.0302 & 20 \\
\hline MABI (dummy) & 0.0479 & 0.0100 & 4.7828 & 0.0000 & 20 \\
\hline
\end{tabular}

As the independent variables primarily contained 2001-2011 variances, there was hardly any interdependence within the independent variables. An optimal best subset regression with (VIF<2.1) and independent variable ( $p$-values $<0.05$ ) was calculated. The study has a reasonable fit $\left(R^{2}\right.$ of $48.3 \%$ and $\mathrm{Adj}$. $\mathrm{R}^{2}$ of $48.1 \%$ ).

$\beta$-value results of control independent variables in the regression are as expected: an increase in neighbourhood poverty is mostly correlated with factors linked to national socio-economic policies outside the scope of the neighbourhood, including decreasing mean monthly household incomes, increasing neighbourhood GINI inequality, decreasing employment rates, decreasing neighbourhood GVA, declining education rates (as a product of a failing national scholastic system), decreasing racial heterogeneity (stemming from selective outmigration), increasing dependency rates (due to high birth rates), and increasing ratios of female-headed households. However, the important variables are the dummy policy variables. In Table 2, the regression indicates that both the national URP and the $\mathrm{MABI}$ programmes are significantly correlated with increases in neighbourhood poverty, with neighbourhood poverty increases higher in MABIs (4.8\%) than in the URP areas (2.3\%). This does not necessarily imply that $A B I s$ are causal factors in increases in neighbourhood poverty; it only indicates that these initiatives were ineffective in reducing neighbourhood poverty rates.

In Table 3, the second analysis presents DD multiple regression analyses of factors related to changes in neighbourhood poverty between 2001 and 2011 in both the study and the control areas. This analysis includes all the independent variables of the first analysis, except the $A B I$ dummy variables. The analysis is conducted at a level of significance ( $p$-values<0.05) with $(\mathrm{VIF}<2.5)$. All the studies have good fits, particularly the treatment groups. In all three areas, the change in neighbourhood poverty, evident as increasing neighbourhood poverty levels (as indicated in Table 2), is correlated with declining mean household income (as a percentage of the mean household incomes in the municipality) and increasing neighbourhood GINI inequality, factors that cannot be indirectly addressed by area-based approaches, but are related to the economic conditions in the country as a whole.

An important first observation is that state investment and increasing basic services provision was not significant in any of the treatment groups, indicating that the extent of $A B I$ interventions was insufficient in effecting change in poverty levels. In the uppermost URP regression in Table 3, policy effects in the treatment group include declining residential densities, declining crime rates and increasing informal dwelling ratios. Controlling for extraneous factors in control groups, the DD regression indicates that increases in GINI inequalities in the URP study areas were both significant and double that of control groups, further indicating a possible failure of policy. Because the household income variances are similar between the URP treatment group and the control group, it can be reasoned that declining neighbourhood income is not a product of $A B I$ policies. However, the significance of increasing in-migration and rapid demographic change indicates that increasing poverty could be the result of the in-migration of the poor rather than neighbourhood or policy effects.

In the middle $\mathrm{MABI}$ regression summary in Table 3, treatment effects, controlling for extraneous effects in control groups indicates that the only direct possible positive policy effect is an increase in employment. However, poverty levels also generally increased relative to increases in the employment rate. Increasing neighbourhood poverty is also significantly correlated with rapid demographic change, declining dependency ratios, declining in-migration rates, significant increases in GINI income inequality, and significantly declining household incomes, controlling for difference-in-differences. These indicate the possible occurrence of hypersegregation effects as a potential negative outcome of $\mathrm{MABI}$ policies.

\section{DISCUSSION AND CONCLUSION}

The study analysed the effect of ABIs on neighbourhood poverty in South Africa. The implementation of $\mathrm{ABls}$ is a controversial issue, with urban managers and business interests favouring this mechanism to target resources in deprived neighbourhoods, in order to reduce poverty levels. However, many researchers and community groups oppose the implementation of ABIs as either ineffective or instrumental 
Table 3: Multiple regression analyses of factors related to changes in neighbourhood poverty, 2001-2011, in the URP, MABI and control areas, respectively.

URP best subset regression; DV: poverty trajectory 2001-2011 (positive value = increased poverty) $R=.9456, R^{2}=.8941$, Adj $R^{2}=.8746, F(7,46)=45.832, p<0.0001$, Std.Err.: .04358

\begin{tabular}{|l|c|c|c|c|c|}
\hline \multicolumn{1}{|c|}{$N=46$} & $b$ & $\begin{array}{c}\text { Std. Err. } \\
\text { (of } b \text { ) }\end{array}$ & $t(46)$ & $p$-value & \# best 20 \\
\hline Intercept & 0.0200 & 0.0208 & 0.9587 & 0.3438 & \\
\hline$\Delta$ Migration rate (\%) & 0.1752 & 0.0452 & 3.8786 & 0.0004 & 20 \\
\hline$\Delta$ Residential density (\%) & -0.0320 & 0.0101 & -3.1658 & 0.0030 & 14 \\
\hline$\Delta$ Racial demographic composition (\%) & 0.2928 & 0.0554 & 5.2818 & 0.0000 & 20 \\
\hline$\Delta$ Household income (\%) & -0.2045 & 0.0196 & -10.462 & 0.0000 & 20 \\
\hline$\Delta$ Neighbourhood GINI (\%) & 0.9584 & 0.1061 & 9.0288 & 0.0000 & 20 \\
\hline$\Delta$ Crime rate (\%) & -0.6091 & 0.2695 & -2.2601 & 0.0296 & 6 \\
\hline$\Delta$ Informal dwelling ratio (\%) & 0.2224 & 0.0324 & 6.8617 & 0.0000 & 6 \\
\hline MARGIN Best sub & &
\end{tabular}

MARGIN Best subset regression; DV: poverty trajectory 2001-2011 (positive value $=$ increased poverty), $R=.9233, R^{2}=.8525$, Adj $R^{2}=.8348, F(6,57)=48.173, p<0.0001$, Std.Err.: .0416

\begin{tabular}{|l|c|c|c|c|c|}
\hline \multicolumn{1}{|c|}{$\mathrm{N}=57$} & $b$ & $\begin{array}{c}\text { Std.Err. } \\
\text { (of } b)\end{array}$ & $t(57)$ & $p$-value & \# best 20 \\
\hline Intercept & -0.0739 & 0.0185 & -3.9915 & 0.0002 & \\
\hline$\Delta$ Migration rate (\%) & -0.0056 & 0.0254 & -2.9766 & 0.0045 & 17 \\
\hline$\Delta$ Racial demographic composition (\%) & 0.1707 & 0.0599 & 2.8495 & 0.0063 & 20 \\
\hline$\Delta$ Household income (\%) & -0.4127 & 0.0343 & -12.030 & 0.0000 & 20 \\
\hline$\Delta$ Neighbourhood GINI (\%) & 0.8088 & 0.0933 & 8.6643 & 0.0000 & 20 \\
\hline$\Delta$ Dependency ratio (\%) & -0.3307 & 0.1425 & -2.3209 & 0.0244 & 9 \\
\hline$\Delta$ Employment rates (\%) & 0.2356 & 0.1003 & 2.3488 & 0.0228 & 4
\end{tabular}

CONTROL Best subset regression; DV: poverty trajectory 2001-2011 (positive value $=$ increased poverty), $R=.8503, R^{2}=.7230$, Adj $R^{2}=.7032, F(4,61)=36.549, p<0.0001$, Std.Err.: 0609

\begin{tabular}{|l|c|c|c|c|c|}
\hline \multicolumn{1}{|c|}{$N=61$} & $b$ & $\begin{array}{c}\text { Std.Err. } \\
\text { (of } b \text { ) }\end{array}$ & $t(61)$ & $p$-value & \# best 20 \\
\hline Intercept & -0.0285 & 0.0114 & -2.5007 & 0.0153 & \\
\hline$\Delta$ Household income (\% of munic. mean) & -0.1612 & 0.0150 & -10.720 & 0.0000 & 20 \\
\hline$\Delta$ Neighbourhood GINI (\%) & 0.4941 & 0.0853 & 5.7927 & 0.0000 & 20 \\
\hline$\Delta$ Female-headed households ratio (\%) & 0.1924 & 0.0904 & 2.1285 & 0.0377 & 20 \\
\hline$\Delta$ Service provision levels (\%) & 0.6443 & 0.1899 & 3.3934 & 0.0013 & 20 \\
\hline
\end{tabular}

in destabilising impoverished neighbourhoods. In this study, two specific ABIs were evaluated in a controlled baseline study. The first policy, the URP, is a national pilot programme implemented in two districts. The second policy, the MABI, is a spatially targeted programme with the focus on municipal budget expenditures in neighbourhoods based on their level of deprivation. In addition, a control group was selected consisting of impoverished neighbourhoods, which were not selected for the URP or the MABI policy areas, using propensity score matching based on the neighbourhood poverty rates and unemployment rates.

Seven hundred and thirty four subplaces in residential neighbourhoods in the Cape Town Municipality were selected for analysis. The study used multiple linear regression with a DD methodology to determine a subset of factors based on correlating neighbourhood poverty with $\mathrm{ABI}$ policies. The first analysis study determined whether the implementation of policies was correlated with changes in neighbourhood poverty between 2001 and 2011. The results of the control variables fitted the expectations of increasing neighbourhood poverty as primarily a product of a range of factors linked to national economic decline and social change, factors which ABIs cannot adequately address. However, there is some scope for localised socio-economic improvements, using small-scale industrial and commercial projects as well as localised education programmes. A bricks-and-mortar approach in ABIs can address certain significantly correlated factors such as decreasing property values and increasing informal dwelling ratios through property-led regeneration. Moreover, specific quick-win projects such as small-scale industrial and commercial development and localised education policies can result in localised improvements in the study areas.
Most importantly, the analysis of $A B I$ dummy variables indicated that neighbourhood poverty in the study area is significantly correlated with increased poverty in both the $\mathrm{ABI}$ areas. This indicates that the ABIs were unsuccessful in targeting neighbourhood poverty. However, it is not certain whether increases in neighbourhood poverty were the result of policy effects or exogenous regional effects, which motivated the second analysis.

The second analysis used a DD methodology to determine what factors are significantly correlated with changes in neighbourhood poverty within both the treatment and the control groups between 2001 and 2011. This was done to determine the effectiveness of $A B I$ policies by establishing whether the correlation between policy and neighbourhood poverty change was a product of policy itself or merely the result of broader changes in regional attributes. An important first observation is that state investment was not significant in any of these instances, indicating that the extent of $A B I$ interventions was insufficient in effecting change in poverty levels. In all three areas, increases in neighbourhood poverty were significantly correlated with declining household incomes and increasing GINI income inequality. This indicates that increases in neighbourhood poverty in the $A B I$ areas is not the product of perverse spillovers from the policy itself, but due to declining incomes linked to the structure of the national economy, factors which cannot be addressed by ABIs.

The potential positive policy effects of URP policies in the URP treatment group are declining residential densities, which can be explained as a product of an expansive publically subsidised housing programme. The other positive effect, declining crime rates, is probably linked to exogenous policing initiatives. The significant correlation between increasing neighbourhood poverty and increasing informal dwelling ratios could indicate that the roll-out of public and private housing was ineffective in reducing backyard housing and the growth of informal 
settlements. Furthermore, controlling for difference-in-differences using control groups, increases in GINI inequalities were double those of control groups, further indicating a possible failure of policy. It appears that, as the URP policy was not specifically designed for poverty alleviation, it could have reduced the potential positive spillovers of ABIs, including improved service delivery, educational outcomes and local employment. There were no significant social gains in terms of health, educational and demographic improvements. Moreover, anecdotal evidence from other studies indicates that the URP resulted in further inequalities linked to the private housing and commercial property development. In addition, the empirical evaluation of the URP initiative is limited, as increasing in-migration and racial demographic change dilute the effects of policy treatments in URP study areas. This can also explain the correlation with increases in the informal dwelling ratio in this treatment group.

In the MABI group, which specifically targeted neighbourhood poverty, the only direct possible positive policy effect is an increase in employment. However, this occurred with significant increases in GINI income inequality and declining household incomes, double that of control groups. Moreover, neighbourhood poverty was also significantly correlated with factors related to hypersegregation, including rapid demographic change, declining dependency ratios, and declining in-migration rates. These outcomes were the opposite of the social cohesive agenda that $\mathrm{ABI}$ intend to engender.

In summary, it appears that ABls were ineffective in lowering neighbourhood poverty, with increasing neighbourhood poverty attributed to exogenous national policies. There was an insufficient level of public investment in ABIs to lower poverty levels, with state investment insignificantly correlated in both study areas. Secondary policy gains achieved were limited, with the URP areas only experiencing decreased densities as a result of public housing. However, adverse effects included increased informality and declining economic growth, due to the adverse effect of retail development. In the MABI areas, possible policy effects could include increasing employment rates, despite increases in income inequality and declining household income, with possible adverse outcomes, including hypersegregation effects. Thus ABI policy outcomes are relatively mixed and no clear net positive outcomes are evident.

\section{REFERENCES LIST}

ABADIE, A. 2005. Semiparametric difference-in-differences estimators. The Review of Economic Studies, 72(1), pp. 1-19. https://doi. org/10.1111/0034-6527.00321

ALCOCK, P. 2004. Participation or pathology: Contradictory tensions in area-based policy. Social Policy \& Society, 3(2), pp. 87-96. https://doi. org/10.1017/S1474746403001556

ANDERSSON, R. \& MUSTERD, S. 2005. Area-based policies: A critical appraisal. Tijdschrift voor Economische en Sociale Geografie, 96(4), pp. 377-389. https://doi. org/10.1111/j.1467-9663.2005.00470.x

BHORAT, H., OOSTHUIZEN M. \& VAN DER WESTHUIZEN, C. 2012. Estimating a poverty line: An application to free basic municipal services in South Africa. Development Southern Africa, 29(1), pp. 77-96. https://doi.org/ 10.1080/0376835X.2012.645643

CITY OF CAPE TOWN METROPOLITAN MUNICIPALITY (CoCT). 2011a. URP Impact Assessment. Cape Town: City of Cape Town.

CITY OF CAPE TOWN METROPOLITAN MUNICIPALITY (CoCT). 2011b. Cape Town spatial development framework (2011-2012). Cape Town: City of Cape Town.

CITY OF CAPE TOWN METROPOLITAN MUNICIPALITY (CoCT). 2011c. City of Cape Town: Budgets 2007/2008-2013/2014. Cape Town: City of Cape Town.

CITY OF CAPE TOWN METROPOLITAN MUNICIPALITY (CoCT). 2014. Cape Town Census 2011 Socio-Economic Index. Cape Town: City of Cape Town.
DEPARTMENT OF PROVINCIAL AND LOCAL GOVERNMENT (DPLG). 2004. National Urban Renewal Programme: Toolkit for programme managers. Pretoria: Government Printer.

DEPARTMENT OF PROVINCIAL AND LOCAL GOVERNMENT (DPLG). 2007a. National Urban Renewal Programme: Implementation framework. Pretoria: Government Printer.

DEPARTMENT OF PROVINCIAL AND LOCAL GOVERNMENT (DPLG). 2007b. National Urban Renewal Programme: Lessons learnt. Pretoria: Government Printer.

\section{DEPARTMENT OF PROVINCIAL AND LOCAL GOVERNMENT (DPLG). 2007c. The Urban Renewal Programme: Monitoring and evaluation framework. Pretoria: Government Printer.}

DONALDSON, R. \& DU PLESSIS, D. 2013. The urban renewal programme as an area-based approach to renew townships: The experience from Khayelitsha's Central Business District, Cape Town. Habitat International, 39(2013), pp. 295-301. https://doi. org/10.1016/j.habitatint.2012.10.012

DONALDSON, R., DU PLESSIS, D., SPOCTER, M. \& MASSEY, R. 2013. The South African area-based urban renewal programme: Experiences from Cape Town. Journal of Housing and the Built Environment, 28(1), pp. 629-638. https://doi.org/10.1007/ s10901-013-9348-3

FORSTER, C., LEON, B. \& MENGUELE, F. 2006. Sharing learning from a DPLG/GTZ/EC urban renewal nodes support initiative. Durban: eThekwini Metropolitan Municipality.

GALSTER, G.C. 2001. On the nature of neighbourhood. Urban Studies, 38(12), pp. 2111-2124. https://doi. org/10.1080/00420980120087072

GOEDEMÉ, T. \& ROTTIERS, S. 2011. Poverty in the Enlarged European Union: A discussion about definitions and reference groups. Sociology Compass, 5(1), pp. 77-91. https://doi. org/10.1111/j.1751-9020.2010.00350.x

HARRISON, P., TODES, A. \& WATSON, V. 2007. Planning and transformation: Learning from the post-apartheid experience. London: Routledge. 
JARGOWSKY, P.A. 2003. Stunning progress hidden problems: The dramatic decline of concentrated poverty in the 1990s. Washington: Brookings Institution.

LALDAPARSAD, S., GEYER, H. Jr \& DU PLESSIS, D. 2013. The reshaping of urban structure in South Africa through municipal capital investment: Evidence from three municipalities. Town and Regional Planning, 63(4), pp.37-48.

LAWLESS, P., FODEN, M., WILSON, I. \& BEATTY, C. 2010. Understanding area-based regeneration: The New Deal for Communities Programme in England. Urban Studies, 47(2), pp. 257-275. https://doi. org/10.1177/0042098009348324

LOGAN, J. \& MOLOTCH, H. 1987. Urban fortunes: The political economy of place. Los Angeles: University of California Press.

MUSTERD, S. \& DE WINTER, M. 1998. Conditions for spatial segregation: Some European perspectives. International Journal of Urban and Regional Research, 22(4), pp. 665-673. https://doi. org/10.1111/1468-2427.00168

NOBLE, M. \& WRIGHT, G. 2013. Using indicators of multiple deprivation to demonstrate the spatial legacy of apartheid in South Africa. Social Indicators Research, 112(1), pp. 187-201. https://doi.org/10.1007/ s11205-012-0047-3

PRAK, N.L., ROBINSON, P., MCCARTHY, J. \& FORSTER, C. 2004. Urban reconstruction in the developing world. Sandown: Heinemann.

REN, C. 2012. Modeling poverty dynamics in moderate-poverty neighborhoods: A multi-level approach. The Columbus: Ohio State University.

SIYONGWANA, P. \& MAYEKISO, T.

2011. Local community and stakeholder participation in post-apartheid urban renewal development projects in Port Elizabeth, South Africa. Africa Insight, 41(3), pp. 142-156.

SMITH, G. 1999. Area-based initiatives: The rationale and options for area targeting. CASE paper No. 25. London: London School of Economics.

SMITH, N. 2002. New globalism, new urbanism: Gentrification as global urban strategy. Antipode, 34(3), pp. 427-450. https://doi. org/10.1111/1467-8330.00249
TEMKIN, K. \& ROHE, W. 1996.

Neighborhood change and urban policy.

Journal of Planning Education and

Research, 15(3), pp. 159-170. https:// doi.org/10.1177/0739456X9601500301

TUROK, I. 1992. Property-led urban regeneration: Panacea or placebo? Environment and Planning A, 24(3), pp. 361-379. https://doi.org/10.1068/ a240361

TUROK, I. 2004. The rationale for area-based policies: Lessons from international experience. In: Robinson, P., McCarthy, J. \& Forster C. (Eds). Urban reconstruction in the developing world: Learning through an international best practice. Cape Town: Heinemann, pp. 405-412.

WILSON, W.J. 1987. The truly disadvantaged: The inner city, the underclass, and public policy. Chicago: University of Chicago Press. 